\title{
MYANMAR'S TRYST WITH DEMOCRACY: LESSONS FROM INDIA
}

\author{
Amrita Dey*
}

\begin{abstract}
Although nascent and pre-matured, there is no doubt that, whatever 'attention' and 'spotlight' Myanmar is enjoying today is all because of 'democracy' and attempts at 'democratic transition' undertaken by President Thein Sein's government in power since 2010. In the political front, the President released most political prisoners from exile; freed Daw Aung San Suu Kyi from house arrest; amended the electoral laws to enable her and the National League for Democracy (NLD) to contest the parliamentary by-elections (Suu Kyi has joined the parliament now as the main opposition party); freed the media and allowed civil society groups to function more freely in the country. In the critical domain of ethnic relations, the President promised that, his government would seek to solve the root causes of ethnic problems through political means and even organize a nation-wide ceasefire agreement to enable lasting peace among its ethnic communities. In other social and economic sectors, the President has undertaken commendable changes aimed at boosting economic growth and sustainable development at the grassroots level. But beneath the façade of seeming progresses, critics fear the motives behind democratization in Myanmar, given the present administration's stubbornness in amending/rewriting the 2008 constitution, it's slackened pace in arresting corruption and ensuring people-centric development in the poverty-stricken/ethnically deprived areas of the country. The present paper is an attempt to compare and contrast Myanmar's experiment with democratization vis-à-vis India whose tryst with democracy, pluralism and capacity building has made it a model for discussion at home and abroad. India's electoral process, experiment with federalism, an independent judiciary and a vibrant media has lessons that can not only make Myanmar's democratic transition irreversible, but enable the two neighbours to jointly address their common problems of insurgency, corruption, unemployment and all inclusive governance.
\end{abstract}

\footnotetext{
* Dr. Amrita Dey is an M.A and PhD in International Relations from Jawaharlal Nehru University, New Delhi (with Southeast Asia as her specialization). Having graduated from Presidency College, Kolkata, she has taught as a guest lecturer in the Department of South \& Southeast Asian Studies, University of Calcutta at the M.A part II level and as a research associate of the centre for more than three years. She has also worked as a journalist of the English Daily, The Statesman for three years. Her publications includes her own book, perspective articles, chapters in edited books, conference proceedings and articles in national and internal journals of repute. She is presently working as a fellow at Maulana Abul Kalam Azad Institute of Asian Studies in Kolkata on the project titled, 'India and Myanmar Relations: Paving the Way for Constructive Engagement' (post 2010). Research fields: International Relations, Security Issues and Southeast Asia.
} 


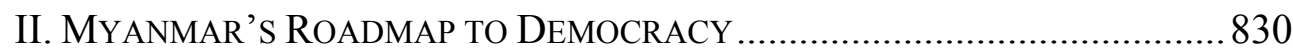

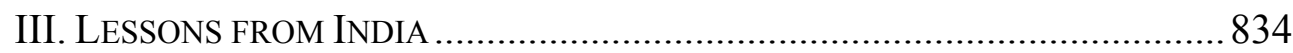

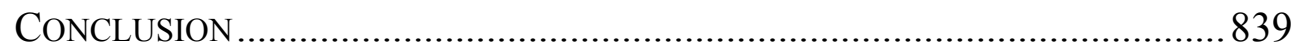

\section{BASIC ‘TENETS' OF DEMOCRACY}

Since the Greek historian Herodotus coined the word 'democracy' in the fifth century $\mathrm{BC}$, the basic tenets of it remain the same, signifying the 'rule of the people'. While, Plato and Aristotle classified 'democracy' as the perverted form of government, signifying 'the rule of many' who disregard the common interest, Abraham Lincoln in his Gattysberg address (1863) said: "Democracy is government of the people, by the people and for the people". Other classical thinkers on democracy-A. V. Dicey and James Bryce saw it as a form of government, "the rule of the people expressing their sovereign will through votes". The people in democracy, according to Bryce, exercised their authority in two ways: (a) they determine the ends towards which their government shall aim; and (b) watch over those into whose hands they have placed the power of administration. Later, John Locke/John Stuart Mill, arguing in favour of liberal democracy, asserted that, liberty and democracy, taken together, created the possibility of 'human excellence', as representative democracy made governments accountable to citizenry and created wiser denizens capable of pursuing their public interest. Jean Jacques Rousseau in his 'Social Contract' vied for direct democracy, where an active, involved citizenry met together to decide what is best for the community and enact appropriate laws. In his own words, Rousseau said: "the people require a government to coordinate public meetings, serve as means of communication, draft laws and enforce the legal system". Such governments shall be constantly accountable to the people for fulfilling the instructions of the 'general will'. Should it fail to fulfil this obligation, it can be revoked and replaced. ${ }^{1}$

Unlike traditional theories which were chiefly concerned with democracy as a form of government, contemporary theories tried to reformulate the notion in the light of sociological findings.

Vilfredo Pareto, Gaetano Mosca and Robert Michels, in their 'elitist theory' divided society into two groups: the rulers and the ruled-the ruling class controlling most of the wealth, power and prestige in society as they exercised all power, whatever form of government that might be. The ruled were not competent to replace it.

Against Pareto and Mosca, Karl Mannhein, Joseph. A Schumpeter,

\footnotetext{
${ }^{1}$ OP Gauba, An Introduction to Political Theory 421-61 (Delhi: Macmillan Pvt Ltd 2003).
} 
championed for reconciliation between the elite and democratic theory. Mannhein argued that, society did not cease to be democratic by entrusting the actual shaping of policy to the elites. In a democracy, the governed can always act to remove their leaders or force them to take decisions in the interests of the many. Schumpeter in his Capitalism, Socialism and Democracy, argued that, democracy, unlike other forms of government, does not allow political leadership to wield absolute power. It had scopes to draw up policies with an eye on gaining a larger support of the electorate.

As a further advancement over Mannhein and Schumpeter, Raymond Aron combined liberal democracy with elite theory, as liberal democracy, according to Aron, was characterized by a general system of checks and balances and plurality of elites. With plurality of elites, according to Aron, government becomes a business of compromise, which are not only sensitive to public opinion but are also conscious of the opposition with which they have to change seats in due course. ${ }^{2}$

From plurality of elites, scholars gradually moved to pluralism and group theory in general, as they called for a revision of the democratic theory itself as well as of the elitist theory. The gist of this pluralistic democracy, forwarded by Robert Dahl, Truman and E. Latham, maybe given as follows: the policy-making process, however centralized it may appear in form, is in reality, a highly decentralized process of bargaining among relatively autonomous groups. In other words, public policy is not a product of the will of the elite or the chosen few-it is an outcome of the interaction of all groups who make claims or express interest in that particular issue. ${ }^{3}$

From here, it further moved to the concept of participatory democracy which called for the active involvement of individuals and groups in the governmental processes affecting their lives. The main objectives of participatory democracy were sought to be achieved through; decentralization; extensive use of referendum and citizen participation. In socialist countries, the concept of participatory democracy, recognized the superiority of the 'proletariat' and sought to bridge the gap between leaders and followers by encouraging mass participation in the socialist program and making leaders responsive to the sentiments of ordinary people.

In Marxian terminology, so long as the state is in existence, with its vast coercive apparatus, there is no difference between bourgeois democracy and dictatorship. Hence, the concept of people's democracy, which called for the 'dictatorship of the proletariat' which only could be realized in a

\footnotetext{
${ }^{2}$ Ibid, at 421-61.

${ }^{3}$ C. B. Macpherson, Democratic Theory-Essays in Retrieval (Oxford: Clarendon Press 1973).
} 
classless society, or at best, in a socialist state which represented uniform interest of the working class. Later, C. B. Macpherson, in his Democratic Theory-Essays in Retrieval developed a new radical theory of democracy, based on a humanist vision, as he claimed to emancipate human beings from the constraints of prevailing social order of the capitalist world and usher in a new society, aimed at promoting 'creative freedom'.

In a nutshell, democracy as an ideal can neither be achieved only through political institutions, nor through transformation of the mode of production. It has to be achieved simultaneously in all spheres: in the legal and political sphere through constitutional structures; in the economic sphere through socialist mode of material production; and in the cultural sphere through inculcation of values of human equality. Or it would become an 'imperfect' 'half-hearted' attempt, susceptible to 'decay' at any point of time.

\section{MYANMAR’S ROADMAP TO DEMOCRACY}

In analyzing Myanmar's transition to democracy, one has to go back to 2003 when the State Peace and Development Council (SPDC) adopted its "Seven-Step Roadmap to Democracy"- the first four steps of which were related to the development of a new constitution which was adopted in 2008 (the constitution was drafted virtually with no public participation and was approved in a referendum orchestrated by the regime): the 2010 elections being the fifth step in this 'Roadmap'; with Step VI convening a meeting for parliament and Step-VII calling for the transfer of power to the new government, headed by the military-turned civilian President Thein Sein. ${ }^{4}$

\begin{tabular}{|c|c|c|}
\hline \multicolumn{2}{|c|}{ Disciplined Democracy } & \\
\hline & \multicolumn{2}{|c|}{ Step VII: Transfer power to new government } \\
\hline & \multicolumn{2}{|c|}{2011 Step VI: To convene meeting for Parliament } \\
\hline & \multicolumn{2}{|c|}{2010 Step V: To hold free and fair elections } \\
\hline & \multicolumn{2}{|c|}{2008 Step IV: To hold national referendum } \\
\hline & \multicolumn{2}{|c|}{2004 Step III: To draw up a draft constitution } \\
\hline & \multicolumn{2}{|c|}{1996 Step II: To implement step by step the request task } \\
\hline & \multicolumn{2}{|c|}{1993 Step I: To resume NC } \\
\hline
\end{tabular}

1988 Military Coup

Fig. 1 The Seven Steps Roadmap to Democracy. Source Hobson's Choice: Burma's 2010 Elections.

\footnotetext{
${ }^{4}$ Hobson's Choice: Burma's 2010 Elections (Thailand: Burma News International 2011) Available at http://www.bnionline.net, accessed 1 May, 2015.
} 
Most scholars, however, argue that, the transition of Myanmar to a genuinely democratic civilian-controlled administration will take time. One of the prime reasons for this is the continued autonomy and lack of political accountability of the armed forces (better known as the Tatmadow) to any of the three branches of the republic and the constitutional powers it enjoys. A few instances will explain this matter more clearly.

One, it has five of the eleven seats on the powerful National Defense and Security Council, which meets almost weekly and has peak decisionmaking authority over matters like granting of amnesties, appointment of the commander-in-chief and declare emergency. The Tatmadow's 25 percent bloc of legislative seats in the parliament gives it the power to veto constitutional changes and influence the outcome of legislative deliberations. It has considerable constitutional autonomy in deciding military and security matters, largely free from civilian oversight-the commander-in-chief being a military officer, not the president and the minister of defence, home affairs and border affairs are serving military officers appointed by the commanderin-chief. Thus, it didn't come as a surprise when the parliamentary Review Committee lobbied against amending Article 59(f) of the 2008 constitution that excludes anyone whose spouse or children are foreign nationals from contesting the polls. This clause makes Daw Aung San Suu Kyi unfit for the Presidential candidature as two of her sons are British nationals through their father, the late Michael Aris.

Even among ethnic groups, there are frustrations regarding the pace of national reform in the country. First, while peace talks were continuing, the tatmadow was busy launching attacks - against the Kachin Independence Organisation (KIO), the Ta-ang National Liberation Army and allied Shan State Army-North (SSA-N) in northeast Myanmar. Such operations exacerbated doubts as to who are really making government decisions in the country-President Thein Sein or the tatmadow commander-in-chief Senior General Min Aung Hlaing. Second, under the Thein-Sein-Union Solidarity and Development Program (USDP) government, previous ceasefire agreements with Kachin, Ta'ang and Shan forces has broken down. And opposition groups were further angered by the tatmadow's increasing promotion of ceasefire Border Guard Forces (BGFs) and local militias as a means to pacify the warring factions, some of which were involved in illicit narcotics production and other corrupt activities. Finally, there is growing resentment that while the Thein Sein- government was gaining all the international plaudits and relief from economic sanctions, the tatmadow and government-favoured companies appeared to be using their positions to pursue their own business interests in the ethnic borderlands-whether 
advantaged by ceasefires in the south or by military manoeuvres in the northeast. $^{5}$

Second, the tatmadow (army's) leading role in Burma is no historical accident. Its involvement in the country dates back to the nationalist movement in the 1930s and 40s, during the 1048-52 civil wars, the 1958 caretaker government, the 1962 military coup, in suppressing the 1988 students' movement and forming the government despite NLD's landslide victory in the 1990 elections. These over the years have created "a selfjustifying belief in the army's rights and duties, to super cede other state institutions. In the name of 'One Nation/Race, One Language, One Religion', the military virtually monopolized key economic activities, including the setting up of two enterprises - the Union of Myanmar Economic Holding Ltd (UMEHL) and the Myanmar Economic Corporation, which was headed by the adjunct general. Any other company, including foreign companies, wishing to enter these sectors were required to form joint venture with UMEHL. ${ }^{6}$

After coming to power, President Thein Sein revoked the tax-free status of Tatmadow's holding companies, including import and export taxes. This administration had also wisely shelved the junta's previous plan to castrate dissident ethnic armed forces/militias under the 'border guard forces' by integrating all of them into the military. Instead, it decided to negotiate ceasefires with major ethnic forces followed by political dialogue. But the pace of nationwide ceasefire has been slow as negotiations on behalf of 16 armed ethnic groups are not moving forward as 'hoped'. Skirmishes keep erupting in Kachin and northern Shan state. And media personnel's have confirmed that only 'four' out of the 13 ethnic groups signed the Agreement on Peace and National Reconciliation on the Union Day, with most groups confessing that they were not even aware of such a peace process taking place in the backdrop. ${ }^{7}$

Flemming Ytzen and Mikael Gravers have rightly pointed out that:

The people of Burma/Myanmar (since 1962) have experienced a military government shifting power from one generation of officers to another and taking

\footnotetext{
${ }^{5}$ David I. Steinberg, The Persistence of Military Dominance, Myanmar: The Dynamics of AN Evolving Polity 37-58 (David I. Steinberg ed., USA: Lynne Rienner Publisher 2015). Also see Robert. H. Taylor, The Armed Forces in Myanmar Politics: A Terminating Role (Singapore: ISEAS 2015).

${ }^{6}$ InTERnAtional Crisis Group Briefing On MYANMAR's Military: BaCK TO THE BARRACKs? 1-18 (Yangon/Brussels 2014).

${ }^{7}$ Rapporteur's Report of the Two-Day International Conference on Myanmar: Moving Towards Elections 2015 organized by Maulana Abul Kalam Azad Institute of Asian Studies, Kolkata, 19-20 February, 2015.
} 
limited reform steps by consolidating their power at home and abroad to increase their legitimacy to govern. Reforms are limited because they are intended to be that way. President Thein Sein may be a genuine reformer but many in the military do not truly want to shift to a civilian democracy. Instead, they want to consolidate its existing power by removing some of the obstacles of direct rulingby-force. This could be called rule-by-proxy while keeping the fortunes. ${ }^{8}$

Then there are other problems related to land rights and land use in Myanmar. As previous authoritarian governments arbitrarily confiscated land from its people to forge large-scale infrastructure projects, extract resources and lay down industrial ventures. Although President Thein Sein's government has recognized the seriousness of the problem and enacted laws related to the Farmland vis-à-vis vacant, fallow and virgin lands, there's lot of ambiguity in his promises 'made' and the actions taken on ground. For instance, property holders are to be issued official land-use certificates which in theory must make land tenure more secure than in the past. But the Farmland Law reaffirms Article 37(a) of the 2008 constitution states that, "the Union is the ultimate owner of all lands and all natural resources above and below the ground, above and beneath the water and in the atmosphere in the Union". 9 This gives free-hand to the government to construct special economic zones, hydropower dams, mines or any other project the ministries think will be beneficial, although the law states that, the government must pay compensation in such cases.

The impact of economic reforms in Myanmar as felt by ordinary citizens can be summed up in three main points:

1. Broader access to a wide range of consumer goods and services, followed by lack of physical and institutional infrastructure resulting in higher transaction costs;

2. Low affordability, given poor income levels in the country. While fiscal and monetary policy reforms are necessary, there's a lack of expertise and exposure among those with the task to undertake these reforms, especially among the lower levels;

3. Myanmar's economic opening has brought more competition for entrepreneurs and less job security for workers. And the adventurous lot continues to seek better opportunities at home and abroad. ${ }^{10}$

This follows accusations by the United Nations about human rights

\footnotetext{
${ }^{8}$ Mikael Gravers \& Flemming Ytzen, Whither Burma? BuRMA/MyANMAR: WhERE Now? 417-21 (Mikael Gravers \& Flemming Ytzen eds, Denmark: NIAS Press 2014).

${ }^{9}$ Christina Fink, Re-envisioning Land Rights and Land Tenure, MYANMAR: DYNAMICS OF AN Evolving Polity 252 (David I. Steinberg ed., USA: Lynne Rienner Publishers 2015).

${ }^{10}$ Moe Thuzar \& Tin Maung Maung Than, Economic Reforms: Expectations and Realities, Myanmar: The Dynamics of An Evolving Polity 237-38 (David Steinberg ed.).
} 
violations in the government's dealing with Muslim-minority Rohingya's in Rakhine state, police crackdown on peaceful student protesters, monks and journalist over a proposed new education law, absence of a functioning judiciary, actual freedom of press, women's issues, poor public amenities and speculations over how much free and fairly the elections will be conducted in Myanmar later this year.

As Myanmar's public opinion starkly differs from the way its administration acts (public opinion being in favour of democracy, freedom and an egalitarian society) any positive change in its set up will be met with distinct and vigorous protestations, followed by ambiguous outcomes. Yet since 2011, overtures have been made, opportunities for dialogue at high levels continue, the beginning of increasing space between the state and the individual, dialogue among ethnic groups and a sense of social and economic hope are all present. "A feeling of progress achieved is not misplaced; a sense of cautious optimism is not amiss." ${ }^{11}$ Myanmar in transition is disturbing to many and fraught with difficulties. But this should neither deter internal renovations nor foreign assistance, if realities are noticed and well addressed by all concerned.

\section{LESSONS FROM INDIA}

Although no two countries are same and their process of nationbuilding 'unique', the success of Indian democracy defies many prevailing theories that stipulate the precondition for democracy. India is not an industrialized, developed economy; Indian businessmen and middle class do not fully control the country's politics; India is anything but ethnically homogeneous; and India would probably rank low on a number of attributes of civic culture. Yet, democracy in India has succeeded for more than half the 20th century and seems likely to succeed as well in the 21 st century. India's democracy has proved substantial as well as durable. Here elections have been free and fair, governments have alternated at the centre and in the states; free speech and association are constitutionally protected and widely practised; a free media and strong judiciary have helped India to "move on' without questioning the efficacy of its foundation. "India is a democracy", says Prime Minister Narendra Modi, "not because its constitution says so but because it is a 'matter of faith' for its people and is in our DNA". ${ }^{13}$ This

\footnotetext{
${ }^{11}$ David Steinberg, The Road toward Change and Development, MYANMAR: THE DYNAMICS OF AN Evolving Polity 319-28 (David Steinberg ed.).

${ }^{12}$ Susanne Hoeber Rudolph \& Lloyd I. Rudolph, New Dimensions of Indian Democracy, 13(1) JOURNAL OF DEMOCRACY (2002).

${ }^{13}$ You Don't Need Dictatorship in India, Democracy is in Our DNA, THE INDIAN EXPRESS (8-5-2015).
} 
section examines how democracy in India responded to a variety of challenges - an experience from which Myanmar can draw 'serious lessons/clues' as Daw Suu Kyi during her visit to US acknowledged that reforms in Myanmar are "still a work in progress" and difficulties/obstacles keep Myanmar's transition to a flourishing, disciplined democracy a distant reality: "we are not yet at the end of our struggle but we are getting there", she said. This is equally relevant at a time when the country is preparing a voters list, a census and negotiating a nationwide ceasefire to build a strong and unified Myanmar.

First, India's electoral process which has undergone significant changes from cross-state coalitions to 'vote-banks' to today's 'horizontal mobilization' involving the aam admi (common man), 'maa, mati Manush' as evident in systems of direct democracy. India is a parliamentary democracy with elections being held to national and state legislature every five years. Elections are held on a first-past-the-post basis in explicitly demarcated electoral constituencies. The electoral redistricting is undertaken after each decennial census. India had two censuses so far: one in 1977 and the second in 2001. (The next decennial census is scheduled for the year 2026). The goals of this redistricting exercise are two-fold: first, to equalize the population across electoral districts within each state, and second to redemarcate the electoral constituencies to be reserved for the Scheduled Castes and Tribes in proportion to their increased population share. The redistricting exercise in India is carried out by an independent (non-political) three-member Delimitation Commission, comprised of a former Supreme Court Judge, the Chief Election Commissioner of India and the State Election Commissioner of the state concerned. After examining data from the 2001 census and local maps, consulting with district officials, the Delimitation Commission prepares a detailed draft proposal with proposed boundaries of each electoral constituency. This draft proposal is widely published, public comments are invited and public sittings in one or more places are held to hear the view of the public. Political parties in the state scrutinize these proposals and submit their views for consideration. After taking all these views into account, final reports are published for each state, all of which are approved by the President of India, before implementing them in subsequent elections.

Second, India's military which is strictly kept under civilian control and historically has never been a threat to stage a coup. The President of India is the Supreme Commander of the Indian Armed Forces, which ensures that, the military is subjected to the will of the people (since the President is democratically elected by the people). Police functioning is 
dictated more by politics than by law or administrative guidelines and political parties have played an enormous role in strengthening the institutions and legitimacy of the government over the military. There exists uniformity in system of pay and allowances to the military, which is fixed by the government based on recommendations of a Central Pay Commission. In perks exclusive to the military are free rations, 50 percent concession on air travel in India, free train travel to home station annually, insurance cover, subsidized accommodation for family and concessional purchase on selected items at low rate from government authorized unit run canteens. These canteens come under a central organization which is civilian run under the Ministry of Defence.

Third, its unique experience in the area of federalism where the federalizing factors can be summarized under the following headings: (a) transformation of the party-system from one-party to a 'competitive' multiparty system. Rudolph and Rudolph in their article New Dimensions of Indian Democracy stated that, the dominant-party system of the NehruGandhi era that led to the formation of Congress majority governments was replaced after the ninth parliamentary election in 1989 by a regionalized multiparty system and coalition governments. The 1989 elections resulted in India's first hung parliament. The Janata Party, which held the largest bloc of seats in the 545-member Lok Sabha, became the nucleus of India's first coalition government. Each of four national elections since then had led to coalition governments in which parties based in single states have been key. This shift, according to Rudolph and Rudolph, from dominant-party to multiparty politics and the rise of state parties at the expense of national parties have ensured that multiple diversities - religious, caste, linguistic, cultural and regional parties are not merely represented, but that they have access to power at the national level. ${ }^{14}$ However the 2014 General elections broke the trend of coalition governments once again in favour of a dominant-party system, as Indians voted unanimously for the BJP-led NDA government at the centre. Critics confirm that this sweep has resulted following Narendra Modi's image as a 'common man's saviour', his promise of a transparent, corruption-free India and his party slogan based on 'development and development alone' (aache din ane wale hai). (b) Multilevel federalism enacted through the seventy third and seventy fourth Constitutional amendments. This has made village Panchayat's and municipality's institutions of self-government. The village Panchayat is uniformly made up of three tiers - the gram panchayat, the block panchayat

\footnotetext{
${ }^{14}$ Rudolph and Rudolph, New Dimensions of Indian Democracy, Journal OF DEMOCRACY (2002).
} 
and the zilla parishad with a gram sabha in every village. The Gram Sabha, comprising the assembly of all people, ensures direct democracy at the rural level. Article 243D provides for reservation of seats for scheduled castes and tribes in proportion to their population at all three panchayat levels. One third of these reserved seats are further reserved for women belonging to SC and STs: this reservation is also extended to the office of the Sarpanch at each panchayat level. Article $243 \mathrm{G}$ lays down that, the panchayats are to have 'the power and authority' to implement schemes for economic development and social justice. The eleventh schedule contains a list of subjects including agriculture, land reforms, women and child development and public distribution systems relevant to these schemes. Similarly, Article $243 \mathrm{~W}$ contains a list of subjects pertinent to city municipalities with the seventy fourth Amendment Act, 1992 establishing a uniform structure for Nagar Panchayats, Municipal Councils and Municipal Corporations for urban areas, with reservation of seats for SC, STs and women at each of these levels. ${ }^{15}$ (c) Accommodating Federal Asymmetries by granting special status to states possessing 'special' characteristics: hilly and difficult terrain; sizeable tribal population, international borders; economic and infrastructure deficits; and non-viable finances. The Northeast India, for instance, home to 214 Scheduled Tribes (STs), is given preferential economic and financial allowances under 'special category states', wherein they are entitled to a grant loan ratio of 90:10 from the Union; members of the ST are exempted from income tax. The region has a separate planning body called the North Eastern Council, a separate Ministry of Development of NER; and Article 371 which allows selected tribal groups to maintain their 'self rule' within the broad framework of 'shared rule'.

Fourth, operation of an independent judiciary headed by the Supreme Court (SC) as the highest court of appeal and interpreter and protector of the constitution and fundamental rights of the people of India. Here SC has exercised its powers variedly through: (a) judicial review (it can pronounce upon the constitutional validity of laws passed by the legislature and the executive. On examination if they are found to violate the constitution, they can be declared as illegal, unconstitutional and invalid); (b) judicial activism (a pro-active approach of the judiciary aimed at acting as a 'check' on the executive). According to Rudolph and Rudolph, the Supreme Court's activism marks a particularly novel turn for a body that spent the first four decades after independence in defending the rights of property owners

\footnotetext{
${ }^{15}$ Shefali Jha, Democracy in India—-The State-Institutional Domain (Delhi 2011). Paper prepared for the project on state of democracy in South Asia, Centre for the Study of Developing Societies.
} 
against land redistribution. The court's decision in the 1980s to begin taking a stand against rights abuses against the poor and to hear cases based on public-interest legislation paved the way for judicial activism of the 1990s; (c) The Public Interest Litigation System (PIL) which enables courts of law to initiate and enforce action for securing any significant public or general interest which is being adversely affected by the action of any agency, public or private. Under it any citizen or a group or voluntary organization can suo moto bring to notice any case demanding action for public interest. The court's verdict in the Jessica Lal Murder Case is an instance. Then there are Special and Fast Track Courts which are specially designed to provide speedy justice to the common people. The Supreme Court and High can also challenge the decisions and proceedings of a Court Martial (in a very limited way) through a writ jurisdiction under Article 32 and 226 of the Constitution; the chief of the Army, Navy and Air Force being appointed by the President of India, who is himself a nominal executive and has to exercise his powers with the aid and advise of the council of ministers headed by the Prime Minister. ${ }^{16}$

Five, Media as fourth wing of government-This is perhaps the most revolutionary chapter in the dynamics of Indian politics where media has been instrumental in creating public opinion and has made political accountability more compulsive. The 2014 elections, for instance, have been deeply impacted by the use of social media (as India has 200 million Internet users, 100 million Facebook users and a billion mobile phone users today). And investigative reporting in print and television media has immensely helped in exposing large scale corruptions pulling back the nation. The Commonwealth Games Scam, the Adarsh Housing Society Scam and Cash for Vote Scam are some highpoints of Indian media. Other initiatives have come in the form of community media for citizens to air their concerns. Here importance lies more in participatory communication right from the grassroots level, rather than communication which flows top down. Although many argue that with the advent of $24 \times 7$ news media, standard of journalism in India have hit a new low. There are two major reasons for this. First: Many politicians, business tycoons have invested in media houses with a purpose of promoting their political/business interests. Second: With too many news channels on air, journalism has become a highly competitive business and the rat race for TRPs has lowered the quality of the programs.

Six, India's inclusive Growth Agendas that have pulled out more

\footnotetext{
${ }^{16}$ Rudolph and Rudolph, New Dimensions of Indian Democracy, JOURNAL OF DEMOCRACY.
} 
people from poverty. In the last 10 years, more than 140 million Indians have risen above the poverty line and India has been certified as polio-free since January 2014. Indian postal service has earned praises for enetworking and IT induction in all post offices. The Narendra Modi government's Swatch Bharat (Clean India) mission, its commitment to provide toilets in schools, Jan dhan yojna scheme and Make in India program to transform business holds promises of inclusive growth, including progress of the most vulnerable sections of the country.

\section{CONCLUSION}

Although critics view India's democracy as an illusion in which the superstructure of democratic government - a parliament and Prime Minister, periodic elections, constitutionally-guaranteed freedoms hide the reality of on-the-ground authoritarian rule by local landlords, bureaucracy and party bosses buttressed by a culture of caste-based inequality sustained by India's continuing poverty. Yet, many see this illusion as an impressive one. As within two years of independence, through an open and spirited debate, India produced a constitution that guarantees "fundamental rights", a federal and parliamentary system with a significant role for the Supreme Court which over the years has enhanced its powers in the system through decisions that limit parliamentary sovereignty. From the beginning, there was tolerance of peaceful dissent and a wide range of active political association. And despite linguistic, regional differences, the party system has carried on. And there is a vigorous free Press. ${ }^{17}$ On the question of whether democracy is inherently a good thing or not, many feel that, it has clearly been affected by technological progress. They believe that in the age of new technologies, and in particular in the era of the Internet, traditional working methods of democracy are too slow, too abstract, and that the political institutions are too bureaucratised and too ritualised. In the search for alternative solutions, they turn to new movements. This explains the rise of alternative parties, which is not a new phenomenon in Europe. While developing societies in a state of transition from authoritarian regimes/military dictatorships have found themselves subject to forces compelling them in the direction towards progressive democratic reform: extension of political rights to citizens, establishment of limited electoral processes, extension of the ability of independent parties to organize themselves, extension of some degree of freedom of Press and issues of liberty, justice and equality. According to the Economist Intelligence Unit

\footnotetext{
${ }^{17}$ Philip Oldenburg, India's Democracy: Illusion or Reality? 12(3) EdUCATION ABOUT AsIA (2007).
} 
Index of Democracy, in the 1950s, there were 22 countries that qualified as free and democratic and 21 partly free. In 2011, there are 86 countries ranked free and 60 partly free with percentage of countries that are electoral democracies increasing since 1989. On the eve of the International Democracy Day, the UN Secretary General rightly pointed out:

Democracies are not born overnight, nor built in a year, or by holding one or two elections. They require sustained and painstaking work. Yet, once begun, there can be no going back. Reform must be real. People do not seek authoritarianism with a human face. They want a virtuous circle of rights and opportunity under the rule of law, a vibrant civil society and an enterprising private sector, backed by efficient and accountable state institutions. Inclusive dialogue is crucial. Diversity is strength. We must work to promote pluralism and protect the rights of minorities and the vulnerable. And women must be at the centre of efforts to build democratic futures. They have been at the forefront of movements for change. They have a right to a real say in governance and decision-making. The voices of the young must also be heard and heeded. Profound demographic pressures around the world make this an imperative. Faced with bleak prospects and unresponsive governments, young people will act on their own to reclaim their future. ${ }^{18}$

${ }^{18}$ Available at $\mathrm{http} / / / \mathrm{www} . u n . o r g / \mathrm{en} / \mathrm{events} / \mathrm{democracyday} / 2012$. 